\title{
Seed viability of Dimorphandra gardneriana subject to water stress in different temperatures
}

\author{
Germinação e vigor de sementes de Dimorphandra gardneriana \\ submetidas ao estresse hídrico em diferentes temperaturas
}

\author{
Marina Matias Ursulino ${ }^{I^{*}}$ Maria do Perpétuo Socorro Damaceno Costa \\ José George Ferreira Medeiros ${ }^{I}$ Edna Ursulino AlvesII Paulo Costa Araujo \\ Riselane de Lucena Alcantara Bruno II Luciana Rodrigues de Araujo
}

\section{ABSTRACT}

The forest species Dimorphandra gardneriana Tul. is widely used for various pharmacological products, yet few basic studies have been undertaken to understand their ecological and physiological attributes under stress conditions. The goal of this research was to evaluate the seed germination and vigor when subjected to different osmotic potentials and temperatures. Water restriction was simulated with polyethylene glycol 6000 solution (PEG 6000) with osmotic potentials of $0 ;-0,2 ;-0,4 ;-0,6 ;-0,8$, and $-1,0 \mathrm{MPa}$ at temperatures of $20,25,30$, and $35^{\circ} \mathrm{C}$. The effect of the treatment was determined by the germination and vigor (germination speed index, length and phytomass of dry shoot and roots) of the seeds, in an entirely random design with four repetitions. From-0, 4MPa it occurs a drastic reduction in germination and vigor of seeds although these factors were less affected at temperature of $25^{\circ} \mathrm{C}$ up to $-0,2 \mathrm{MPa}$.

Key words: Faveira, water restriction, forest species.

\section{RESUMO}

A espécie florestal Dimorphandra gardneriana Tul.é bastante utilizada para diversos produtos farmacológicos, mesmo assim há poucos estudos básicos para compreender seus atributos ecológicos e fisiológicos sob condições de estresse. Desta forma, o objetivo nesta pesquisa foi avaliar a germinação e o vigor de suas sementes quando submetidas a diferentes potenciais osmóticos e temperaturas. A restrição hídrica foi simulada com solução de polietilenoglicol 6000 (PEG 6000) nos potenciais osmóticos de 0; -0,2; -0,4; -0,6; $-0,8$ e -1,0MPa nas temperaturas constantes de 20, 25, 30 e $35^{\circ} \mathrm{C}$. Na avaliação do efeito dos tratamentos, determinou-se a germinação e o vigor (índice de velocidade de germinação, comprimento e fitomassa seca de parte aérea e raizes) das sementes, em delineamento inteiramente ao acaso, em quatro repetições. A partir de -0,4MPa ocorre redução drástica da germinação e vigor das sementes, fatores estes menos afetados na temperatura de $25^{\circ} \mathrm{C}$ até-0, $2 \mathrm{MPa}$.

Palavras-chave: faveira, restrição hídrica, espécie florestal.

\section{INTRODUCTION}

The species Dimorphandra gardneriana Tul., which belongs to the Fabaceae family, is popularly known as fava d'anta, faveiro, favela, and barbatimão. It is found mainly in the states of Maranhao, Bahia, Goiás, and Ceará (DÔRES, 2007). Its fruit has a high content of flavonoids such as rutin, quercetin, and rhamnose sugar, which form the basis of many pharmacological products such as eye drops (MENDES et al., 2005). According to the authors, rutin is a substance found in fava d'anta seeds and is an important flavonoid due to its vitamin $\mathrm{P}$ activity, which decreases the permeability of red blood cells, protects vitamin $\mathrm{C}$ against oxidation, and normalizes strength and permeability of capillary walls.

The faveira can also be found in the semiarid regions of Brazil - regions characterized by prolonged periods of drought with high temperatures; thus, limiting the development of forest species (FARIAS, 2008). Although typical vegetation of the region has tolerance to water stress, temperature increases due to global warming caused serious shifts in climate,

'Programa de Pós-graduação em Agronomia, Centro de Ciências Agrárias (CCA), Universidade Federal da Paraíba (UFPB), 58397-000, Areia, PB, Brasil. E-mail: marinamatiasu@gmail.com. ${ }^{*}$ Corresponding author.

IIDepartamento de Fitotecnia e Ciências Ambientais, Universidade Federal da Paraíba (UFPB), Areia, PB, Brasil. Received 08.31.12 Approved 06.13.16 Returned by the author 09.30.16 CR-2012-0792.R6 
especially in regions known for water shortages. Further studies on the behavior of species under these conditions will be necessary (ASSAD \& PELLEGRINO, 2007).

The majority of forest species have seeds, which go through periods of dormancy hindering the production of seedlings for nurseries - mainly due to the lack of uniformity and long germination periods (COELHO et al., 2010). Among the various pregermination treatments that can be used to overcome cutaneous dormancy are mechanical scarification (using friction to rub seeds against abrasive surfaces) and chemical treatment (usually with sulfuric acid) (MARCOS FILHO, 2005).

Water is involved directly or indirectly in all metabolic stages of germination. It plays a decisive role in enzymatic reactions, in the solubilization, and transport of metabolites, and as a reagent in the hydrolytic digestion of storage reserve tissues in seeds, such that very negative osmotic potentials retard and decrease the percentage of seeds that germinate (BRADFORD, 1995).

Among the various solutions that simulate conditions of water stress, polyethylene glycol (PEG) is widely used as an osmotic agent (HASEGAWA et al., 1984) due to the fact that it is an inert and non-toxic chemical compound with a high molecular weight that is not absorbed by the seed (HARDEGREE \& EMMERICH, 1994).

Temperature is another factor that influences the rate of seed germination, ynamics of water absorption, limits and speed of biochemical reactions, in addition to the physiological processes that determine germination (MARCOS FILHO, 2005; CARVALHO \& NAKAGAWA, 2012).

Thus, the objective of this research was to evaluate the germination and vigor of Dimorphandra gardneriana Tul. seeds that were subjected to different osmotic potentials and temperatures.

\section{MATERIALS AND METHODS}

The experiment was conducted at the Seed Analysis Laboratory of the Federal University of Paraíba, in the Center for Agricultural Sciences (UFPB-CCA), with Dimorphandra gardneriana Tul. seeds obtained from fruit collected from mother trees in the Araripe chapada plateau in the city of Crato, Ceará, Brazil.

To verify the effect of different water potentials on the germination process, polyethylene glycol (PEG 6000) was used as an osmotic agent. Solutions were prepared in accordance with the procedure described by VILLELA et al. (1991). After PEG 6000 dosages were determined for each osmotic potential, seeds were subjected to tests to evaluate germination and vigor.

The germination test was conducted in a Biological Oxygen Demand (BOD) germination chamber regulated at constant temperatures of 20 , 25,30 , and $35^{\circ} \mathrm{C}$, with a photoperiod of eight hours of light and 16 hours of darkness using daylight fluorescent lamps $(4 \times 20 \mathrm{~W})$. For each treatment, 100 seeds were mechanically scarified with 120 grit metal sandpaper on the side opposite to the hilum, in order to overcome cutaneous dormancy. Then seeds were divided into four repetitions of 25 and distributed on two sheets of Germitest paper towel moistened with solutions that had osmotic potentials of $0 ;-0.2 ;-0.4 ;-0.6 ;-0.8$; and $-1.0 \mathrm{MPa}$, in an amount equivalent to 2.5 times the mass of the dry paper. They were then covered with a third sheet, arranged in rolls, and packed in plastic bags.

First germination count was made on the thirteenth day and the final germination count was made on the twenty-fifth day after test initiation , which used normal seedlings as its criterion.

The speed of germination index was determined by daily counts of number of germinated seeds, at the same time each day, on days 13 to 25 after sowing. The index was calculated according to the formula $\left(S G I=\frac{G}{N_{1}}+\frac{G_{2}}{N_{2}}+\ldots+\frac{G_{n}}{N_{n}}\right)$, proposed by Maguire (1962), where: $S G I=$ speed of germination index, $G_{l}, G_{2}$ and $G n=$ number of seedlings counted in the first, second and last count; and $N_{1}, N_{2}$, and $N n$ $=$ number of days from sowing until the first, second and last count.

Length shoots and of primary root of normal seedlings after each treatment and repetition was measured at the end of the germination test. Each part was measured using a centimeter ruler and results were expressed in seedling $\mathrm{cm}^{-1}$. Dry phytomass of shoots and roots of the same seedlings that were measured in the previous evaluation were placed in Kraft paper bags and dried in an oven at $65^{\circ} \mathrm{C}$ until reaching a constant weight (48 hours), and then samples were weighed on an analytical balance with $0.001 \mathrm{~g}$ precision. Results were expressed in seedling $\mathrm{g}^{-1}$. The experiment and statistical analysis were carried out with a completely randomized design, with treatments distributed in a $4 \times 6$ factorial scheme (temperatures and osmotic potentials) in four repetitions; the data were subjected to the analysis of variance and polynomial regression. 


\section{RESULTS AND DISCUSSION}

\section{Germination of Dimorphandra} gardneriana Tul. seeds was affected by the water potentials used., the germination percentage was reduced from $-0.4 \mathrm{MPa}$ onwards, such that germination above this potential occurred only at the temperature of $25^{\circ} \mathrm{C}$ (Figure 1A). Results observed are consistent with expectations, since ROSA et al. (2005) reported that the osmotic potential of the solution in the germination medium controls the absorption of water by seed tissues; thus, impeding or preventing germination onset.

Low performance of seeds in more negative potentials was evident when they were subjected to temperatures of 20,30 , and $35^{\circ} \mathrm{C}$, in which germination process was negatively affected, confirming that an ideal temperature of around 20 to $25^{\circ} \mathrm{C}$ is required for D. gardneriana seeds to germinate.

Water stress, as simulated with polyethylene glycol, also negatively impacted the germination of some Fabaceae species, such as Adenanthera pavonina L. (FONSECA \& PEREZ, 2003) and Ateleia glazioviana Baill. (ROSA et al., 2005).

A marked reduction as levels of osmotic potential of PEG 6000 solutions decreased was observed from results related to vigor as determined by the first germination count(Figure 1B). This sharp reduction in seed germination at higher PEG concentrations may be attributed mainly to a reduction in the amount of water absorbed by seeds, since CAMPOS \& ASSUNÇÃO (1990) reported that reductions in seed vigor under water stress might be attributed to apparent inhibition of synthesis and/or activity of hydrolytic enzymes, which are necessary for germination as the concentration of the osmotic solutions increases.

Speed of germination index of seeds was also very negatively affected by decreases in the level of osmotic potential of PEG 6000 solutions (Figure 1C), similar to what occurred with respect to germination and vigor as determined by the first germination count.

Water stress can reduce both the percentage of seeds that germinate as well as the speed of

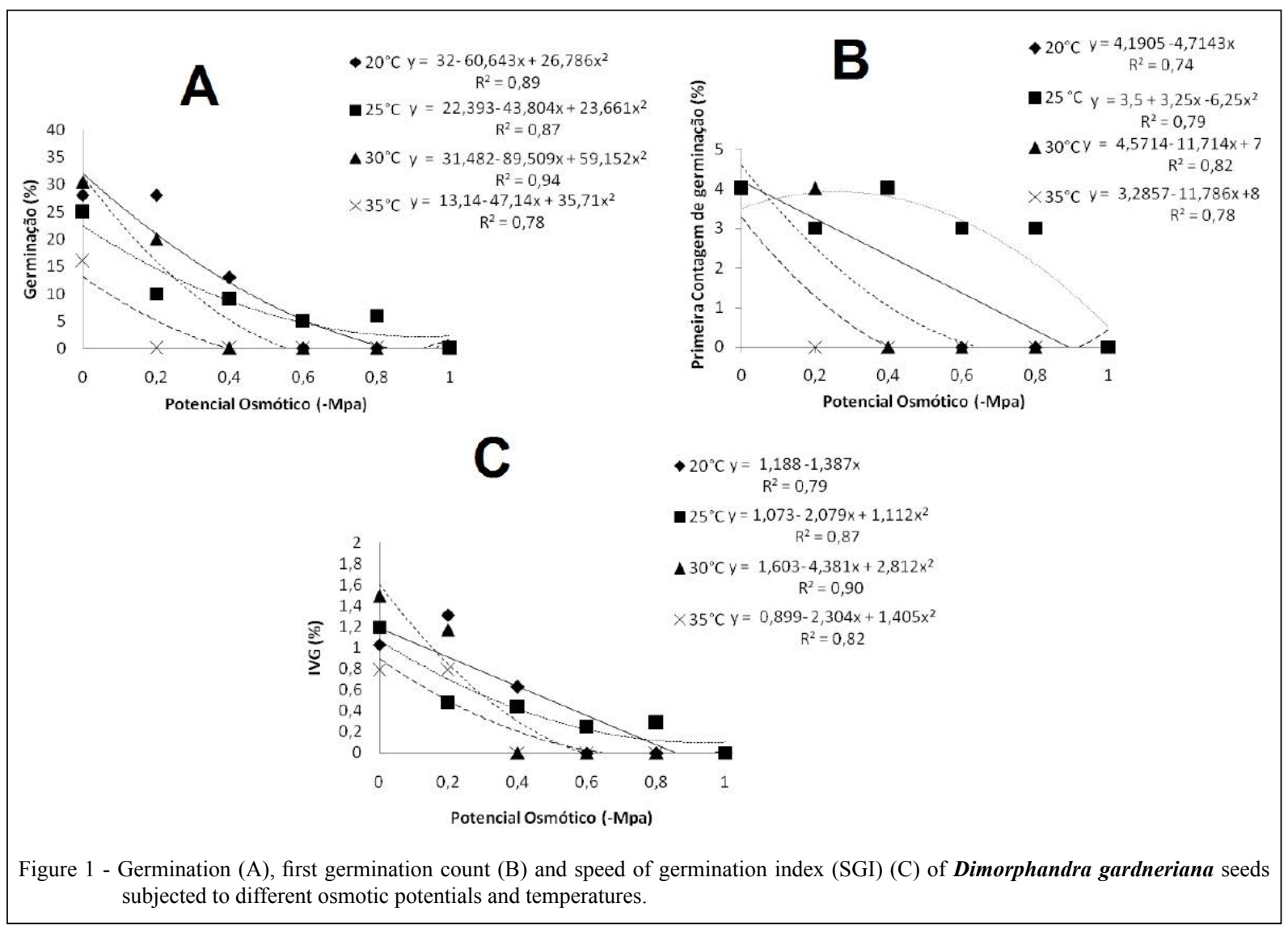

Ciência Rural, v.46, n.12, dez, 2016. 
germination (PEREZ et al., 1998). For Dimorphandra gardneriana Tul. seeds, it was reported that, as osmotic potential increased, there was a need for more time for seeds to swell and germinate and a slower speed of germination was observed. BRUNI \& LEOPOLD (1992) attributed reductions in the speed of germination to a probable loss of protoplasmic swelling, which causes disturbances in cell physiology and damage to systems of biomembranes.

For the Adenanthera pavonina L. species, FONSECA \& PEREZ (2003) observed an increased time required for germination when the osmotic potential of the control increased up to $-0.5 \mathrm{MPa}$. The same result was observed for seeds of the species Senna occidentalis (L.), H.S. Irwin \& R.C. Barneby (DELACHIAVE \& PINHO, 2003) and Chorisia speciosa, St. Hil. (FANTI \& PEREZ, 2003).

Length of shoots and roots of $\boldsymbol{D}$. gardneriana seedlings was also negatively affected by different osmotic potentials and temperatures, in a way that was more significant and similar to the assessments of previous variables, since there was a decrease in the length of seedlings as the potentials became more negative (Figure 2A and B). Shoots and roots with the greatest lengths $(8.5$ and $5.5 \mathrm{~cm}$, respectively) were obtained at the temperature of $30^{\circ} \mathrm{C}$ in the control treatment, when compared to seeds that were subjected to temperatures of 20, 25, and $35^{\circ} \mathrm{C}$ under the same conditions of stress.

In similar studies carried out with Peltophorum dubium (Spreng.) Taub., PEREZ et al. (2001) observed a decrease in the length of seedlings for osmotic potentials from -0.6 to $-0.8 \mathrm{MPa}$. ROSE et al. (2005), working with the same concentrations of PEG 6000 used for D. gardneriana, obtained similar results for the length of Ateleia glazioviana Baill seedlings.

With regard to the dry phytomass content of shoots and roots of D. gardneriana seedlings, the influence of different water potentials and temperatures was observed (Figure 2C and D). Dry phytomass content of shoots of seedlings from seeds that were not subjected to water stress was $0.0133 \mathrm{~g}$ seedling ${ }^{-1}$ at $20^{\circ} \mathrm{C}$ (Figure $2 \mathrm{C}$ ) and, with respect to dry phytomass of roots of seedlings from seeds without water stress, the greatest value $\left(0.0400 \mathrm{~g}^{\text {seedling }}{ }^{-1}\right)$ was reported at $30^{\circ} \mathrm{C}$. Thereafter, the dry phytomass reduced sharply, most notably at the temperature of $35^{\circ} \mathrm{C}$ (Figure 2D).

Water stress acts to reduce the speed of physiological and biochemical processes in

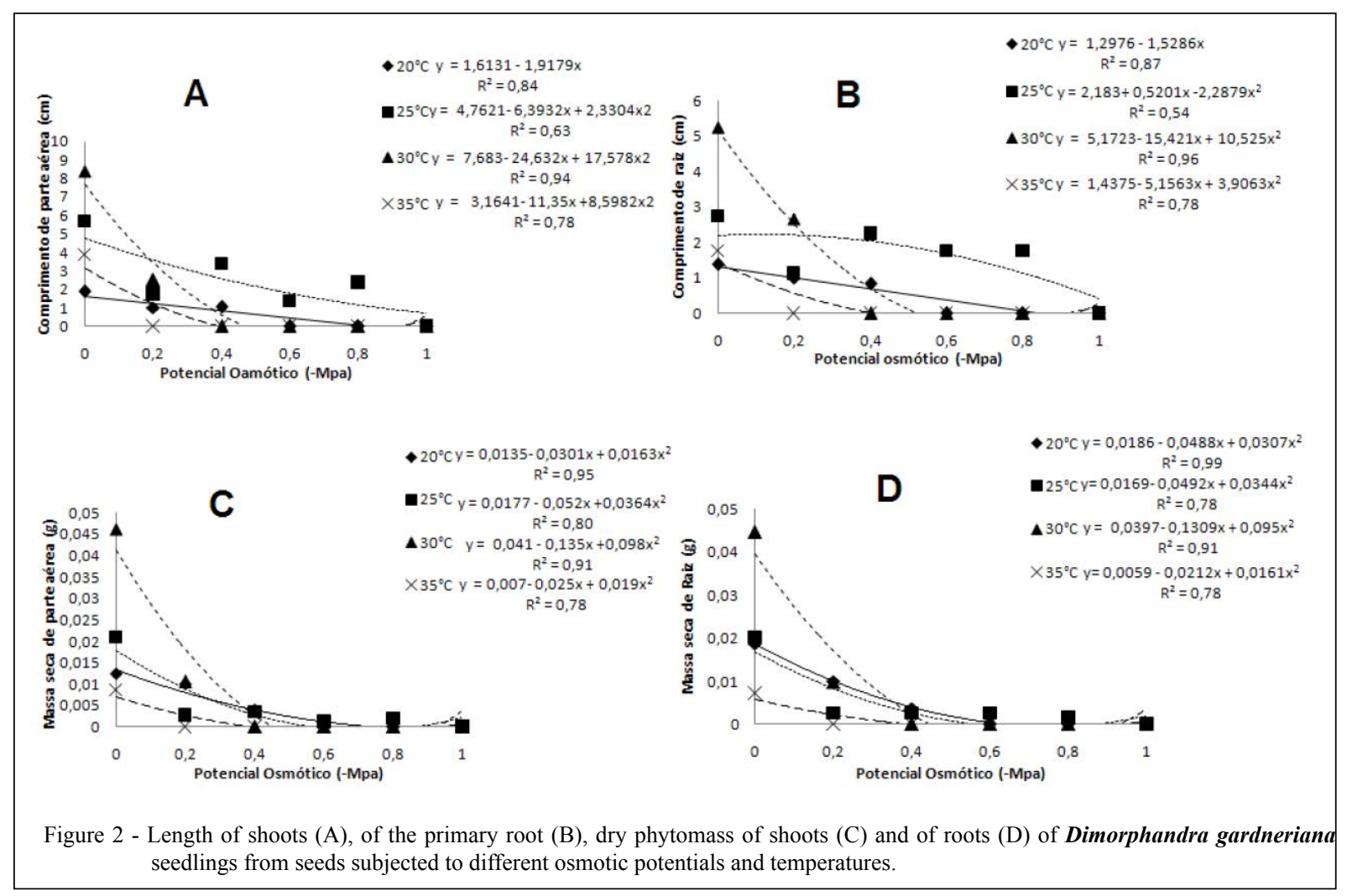

Ciência Rural, v.46, n.12, dez, 2016. 
the seeds resulting in reduced metabolism, which directly affected the length and accumulation of dry phytomass in D. gardneriana seedlings under these stress conditions. BEWLEY \& BLACK (1994) noted that the reduction in dry phytomass of seedlings as a function of water restriction occurs due to the difficulty of hydrolysis and mobilization of seed reserves.

In Ateleia glazioviana Baill. seeds, a decrease in osmotic potential led to significant reductions in dry phytomass of seedlings (ROSA et al., 2005). Some researchers reported that the germination percentage and speed of germination, as well as the accumulation of dry phytomass in low water potentials, might be preliminary indicators for species selection for colonization in environments that are subjected to water deficiency (PEREZ et al., 1998). The D. gardneriana species, due to its high tolerance for water stress, is adaptive because seedlings, which have a greater capacity to tolerate water stress, are able to prevail in dry environments and have a greater ability to establish themselves and survive in these environments.

\section{CONCLUSION}

Simulated water restriction with polyethylene glycol 6000 (PEG 6000), starting at $-0.4 \mathrm{MPa}$, dramatically reduces the germination and early development of Dimorphandra gardneriana Tul. Seedlings.

At a temperature of $25^{\circ} \mathrm{C}$, germination and seed vigor are less affected by water stress up to $-0.2 \mathrm{MPa}$ with regard to all of the characteristics that were assessed.

\section{ACKNOWLEDGEMENTS}

Authors would like to thank the Coordenação de Aperfeiçoamento de Pessoal de Nível Superior (CAPES) for the scholarship awarded to the post-graduate Master's Program researchers in agronomy at the "Center for Agrarian Sciences of Paraiba” municipality of Areia (CCA/UFPB/Areia, PB).

\section{REFERENCES}

ASSAD, E.D.; PELEGRINO, G.Q. O clima e a potência ambiental. Revista Agroanalysis, v.27, n.4, p.E3-E4, 2007. Available from: $<$ http://www.agroanalysis.com.br/especiais_detalhe. php?idEspecial=7\&ordem=2>. Accessed: Sept. 19, 2015.

BEWLEY, J.D.; BLACK, M. Seeds: physiology of development and germination, 2.ed. New York: Plenum, 1994. 445p.

BRADFORD, K.J. Water relations in seed germination. In: KIGEL, J.; GALILI, J. Seed development and germination. New York: Marcel Dekker, 1995. 853p.
BRUNI, F.B.; LEOPOLD, A.C. Cytoplasmic glass formation in maize embryos. Seed Science Research, v.2, n.4, p.251-253, 1992. Available from: $<$ http://dx.doi.org/10.1017/S0960258500001446>. Accessed: Sept. 19, 2012. doi: 10.1017/S0960258500001446.

CAMPOS, I.S.; ASSUNÇÃO, M.V. Effects of sodium chloride on germination and vigor of seedlings of rice. Pesquisa Agropecuária Brasileira, v.25, n.6, p.837-843, 1990. Available from: <https:// seer.sct.embrapa.br/index.php/pab/article/download/13507/7672>. Accessed: Sept. 19, 2012.

CARVALHO, N.M.; NAKAGAWA, J. Sementes: ciência, tecnologia e produção. 5.ed. FUNEP: Jaboticabal, 2012. 590p.

COELHO, M.F.B. et al. Superação da dormência tegumentar em sementes de Caesalpinia ferrea Mart ex Tul. Revista Brasileira de Ciências Agrárias, v.5, n.1, p.74-79, 2010. Available from: $<$ http://www.researchgate.net/publication/240992213>. Accessed: Sept. 19, 2012. doi: 10.5039/agraria.v5i1a570.

DELACHIAVE, M.E.A.; PINHO, S.Z. Germination of Senna occidentalis Link: seed at different osmotic potential levels. Brazilian Archives of Biology and Technology, v.46, n.2, p.163166, 2003. Available from: <http://dx.doi.org/10.1590/S151689132003000200004>. Accessed: Sept. 19, 2012. doi: 10.1590/ S1516-89132003000200004.

DÔRES, R.G.R. Análise morfológica e fitoquímica da favad'anta (Dimorphandra mollis Benth.). 2007. 375f. Tese (Doutorado em Fitotecnia) - Curso de Pós-graduação em Fitotecnia, Universidade Federal de Viçosa, MG.

FANTI, S.C.; PEREZ, S.C.J.G.A. Efeito do estresse hídrico e envelhecimento precoce na viabilidade de sementes osmocondicionadas de paineira (Chorisia speciosa). Pesquisa Agropecuária Brasileira, v.38, n.4, p.537-543, 2003. Available from: <http://dx.doi.org/10.1590/S0100-204X2003000400013>. Accessed: Sept. 19, 2012. doi: 1590/S0100-204X2003000400013.

FARIAS, S.G.G. Estresse osmótico na germinação, crescimento e nutrição mineral da gliricídia (Gliricidia sepium Jacq. Walp.). 2008. 61f. Dissertação (Mestrado em Zootecnia) Curso de Pós-Graduação em Zootecnia, Universidade Federal de Campina Grande.

FONSECA, S.C.L.; PEREZ, S.C.J.G.A. Ação do polietileno glicol na germinação de sementes de Adenanthera payonina L. e o uso de poliaminas na atenuação do estresse hídrico sob diferentes temperaturas. Revista Brasileira de Sementes, v.25, n.1, p.16, 2003. Available from: <http://dx.doi.org/10.1590/S010131222003000100001>. Accessed: Sept. 19, 2012. doi: 10.1590/ S0101-31222003000100001.

HARDEGREE, S.P.; EMMERICH, W.E. Seed germination response to polyethylene glycol solution depth. Seed Science and Technology, v.22, n.1, p.1-7, 1994. Available from: $<$ http://handle. nal.usda.gov/10113/6952>. Accessed: Sept. 19, 2012.

HASEGAWA, P.M. et al. Cellular mechanisms of tolerance to water stress. HortScience, v.19, n.3, p.371-377, 1984.

MAGUIRE, J.D. Speed of germination and in selection and evaluation for seedling emergence and vigor. Crop Science, v.2, n.2, p.176-177, 1962. Available from: <https://www.crops.org/ publications/cs/abstracts/2/2/CS0020020176 $>$. Accessed: Sept. 19, 2012. doi: $10.2135 /$ cropsci1962.0011183X000200020033x. 
MARCOS FILHO, J. Fisiologia de sementes de plantas cultivadas. Piracicaba: FEALQ, 2005. 495p.

MENDES, A.D.R. et al. Produção de biomassa e flavonóides totais por fava-d'anta (Dimorphandra mollis Benth.) sob diferentes níveis de fósforo em solução nutritiva. Revista Brasileira de Plantas Medicinais, v.7, n.2, p.7-11, 2005. Available from: $<$ http://www.sbpmed.org.br/download/issn052/artigo2v7n2.pdf $>$. Accessed: Sept. 19, 2012.

PEREZ, S.C.J.G.A. et al. Influência da temperatura sobre a resistência das sementes de canafístula (Peltophorum dubium (Spreng) Taubert) ao estresse hídrico simulado. Revista Brasileira de Sementes, v.20, n.2, p.96-103, 1998. Available from: $<$ http://www.scielo.br/scielo.php? script $=$ sciserial\&pid $=2317$ 1537\&lng=en\&nrm=iso $>$. Accessed: Sept. 19, 2012. doi: 10.17801/0101-3122/rbs.v20n2p96-103.
PEREZ, S.C.J.G.A. et al. Influência da luz na germinação de sementes de canafístula submetidas ao estresse hídrico. Bragantia, v.60, n.3, p.155-156, 2001. Available from: <http://dx.doi. org/10.1590/S0006-87052001000300002>. Accessed: Sept. 19, 2012. doi: 10.1590/S0006-87052001000300002.

ROSA, L.S. et al. Avaliação da germinação sob diferentes potenciais osmóticos e caracterização morfológica da semente e plântula de Ateleia glazioviana Baill (timbó). Cerne, v.11, n.3, p.306-314, 2005. Available from: <http:/www.redalyc.org/ articulo.oa?id=74411309>. Accessed: Sept. 19, 2012.

VILLELA, F.A. et al. Tabela de potencial osmótico em função da concentração de polietileno glicol 6000 e da temperatura. Pesquisa Agropecuária Brasileira, v.26, n.11/12, p.1957-1968, 1991. Available from: <http://seer.sct.embrapa.br/index.php/pab/article/ view/3549/882>. Accessed: Sept. 19, 2012. 